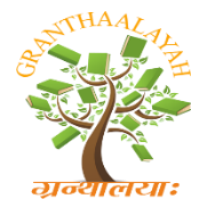

$$
\begin{gathered}
\text { INTERNATIONAL JOURNAL OF RESEARCH } \\
\text { GRANTHAALAYAH } \\
\text { A knowledge Repository }
\end{gathered}
$$

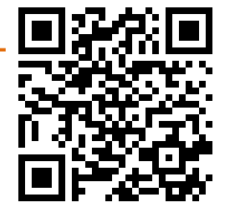

Science

\title{
SOIL FAUNA FOOD WEB IN SEVERAL LAND USE TYPES OF SUPER WET TROPICAL RAIN FOREST AREA
}

\author{
Fenky Marsandi ${ }^{* 1}$, Hermansah ${ }^{2}$, Agustian ${ }^{2}$, Syafrimen Yasin ${ }^{2}$ \\ ${ }^{1}$ Department of Agriculture Science, Student of Doctoral Post-Graduate Program, Universitas \\ Andalas, Limau Manih, Padang, West Sumatra, Indonesia \\ ${ }^{2}$ Department of Soil Science, Universitas Andalas, Limau Manih, Padang, West Sumatra, \\ Indonesia
}

\begin{abstract}
Changes land use in the super-wet tropical rainforest area has resulted in changes pattern of soil fauna food webs that show the diversity of ecosystems. Various soil biodiversity studies tend to prioritize the diversity of soil fauna, without examining how changes in the pattern of food flow are running. The results showed that the abundance of the highest number of functional individuals of soil fauna in each type of land was predator. The diversity of functional types of soil fauna in forest and mixed gardens is also dominated by predators and on open area types and monoculture gardens dominated by herbivorees. While the parasitoid and detritivore groups were spread evenly on each type of land. This shows that the pattern of food webs in each land type of super wet tropical rainforest area reaches a balance in the type of forest and mixed gardens and begins to be disrupted in open area and monoculture gardens. The highest trophic level of food webs is the main controller of ecosystem balance. Changes in vegetation type of land in super wet tropical rain forest area will cause fragmentation of functional habitat of soil fauna which causes imbalance of energy flow in food webs.
\end{abstract}

Keywords: Forest; Soil Fauna; Food Web; Functional; Predator.

Cite This Article: Fenky Marsandi, Hermansah, Agustian, and Syafrimen Yasin. (2019). "SOIL FAUNA FOOD WEB IN SEVERAL LAND USE TYPES OF SUPER WET TROPICAL RAIN FOREST AREA." International Journal of Research - Granthaalayah, 7(5), 327-340. https://doi.org/10.29121/granthaalayah.v7.i5.2019.855.

\section{Introduction}

The main purpose of soil ecology is to understand population dynamics and soil fauna communities. In the soil fauna community it is fundamentally related to the relationship between food and the predator's style in finding prey. To illustrate the complex arrangement of feeding relationships in the food web of the soil fauna community, it has been found in the form of simple 
food web images of soil fauna in a binary way, namely by drawing arrows between prey and predators. This might help in visualizing the main relationships between soil fauna species [1]. In fact, the aim of most soil food webs is to understand the effects of soil fauna communities on the decomposition process and nutrient cycle [2].

Soil fauna food webs perform important ecosystem services needed to maintain agricultural productivity and ecosystem health [3][4]. Food webs describe our understanding of trophic relationships between producers, consumers, predators and decomposers. In the land surface ecosystem, trophic relationships among varied taxa animals while in the underground are very difficult to understand [5][6]. Higher trophic levels in soil food webs can play a role that suppresses the spread of plant parasites and influences nutrient dynamics by modifying the abundance of consumers of soil fauna. The majority of soil fauna living on the soil surface for most of their lives and associated with trophic ecology of soil fauna shows that they are important members of the food web and affect the functioning of soil ecosystems [7].

The super wet tropical rain forest area is an area with high rainfall and humidity $(\geq 6,500 \mathrm{~mm} /$ year) which is accompanied by a high diversity of plants [8]. This area is located on the foothills of Pinang-Pinang which is part of a series of hills in the West Sumatra line where there are forest areas of international ecological research plots [8]. In the present conditions, a portion of this area has changed into several types of land, including open areas, mixed gardens and monoculture gardens. This is a major factor that causes changes in the dynamics of soil fauna food webs through abundance and diversity of soil fauna as an indicator of 'health' of the soil [9]. This group provides key services in forests and agroecosystems such as decomposition of organic matter, soil aeration, and control of pests and diseases [10].

In soil ecology, evaluations are intended to estimate the land effectiveness of management practices in agriculture to have similarities as in natural areas, focused on the abiotic properties of the soil [9]. The study of awareness of soil food webs and their effects on nutritional dynamics has begun to increase [11]. Available micro knowledge, meso and soil macrofauna, based on identification of morphology and functional knowledge. The food web model extends expert knowledge to the conceptual idea of how the soil food web functions, which is still used today [12].

Assessing soil fauna food webs on several types of land is the main objective of the research in the hope that it can be the best alternative in supporting sustainable land development programs that maintain the balance of the soil fauna ecosystem.

\section{Materials and Methods}

Sampling of soil fauna was carried out in four types of land (forests, open areas, mixed gardens and monoculture gardens) Pinang-Pinang hillside area (coordinates 100'29'40 "and 100³0'20" BT and between $0^{\circ} 54^{\prime} 55$ "And $0^{\circ} 55^{\prime} 45^{\prime \prime}$ LS). Whereas the collection and identification of soil fauna was carried out in the Insect Bioekology laboratory, majoring in Pests and Plant Diseases, Andalas University Faculty of Agriculture. The research began in April - November 2018. 
The materials used in this study included Prophylin glycol, alcohol 96\% and aquadest while the tools used included glass cup plastic, mica dish, machete, label paper, P-vott 100 tube ml, tissue, cotton, tweezers, petri dishes, microscopes, cameras and identification books (Borror 1992 and Insect of Australia) / web taxonomy.

The method used in this study is the survey method, where the determination of sample points is done by purposive random sampling based on land toposecurity (low, high and medium) on each type of land, while sampling soil fauna is done by installing pitfall trap traps and using methods handsorting.

Identification of soil fauna was carried out in the laboratory using a stereo microscope by observing all parts of the soil fauna morphology and calculating the number of each soil fauna. then identification of conduct by using the Borror book (Introduction to Insect Types) and Insect of Australia.

Each of these morphological identification results was followed by the identification of functional soil fauna based on food sources in each of these soil fauna. Furthermore, visualization of food nets is made through each type of land.

\section{Results and Discussions}

\subsection{Functional Soil Fauna in Several Types of Land Super Wet Tropical Rainforest Areas}

Soil fauna as an executor of a series of ecosystem processes in a region, causes this component to have an important role in maintaining ecosystem stability. Some types of land that have been formed by humans in the super wet tropical rain forest area cause degradation in the soil fauna group. The degradation of the abundance of soil fauna will affect the functioning of ecosystems in each type of land, where the level of evenness of soil fauna will be disrupted resulting in some soil fauna dominating on a land type.

Functional soil fauna reflects the condition of the ecosystem of a land, where the presence of soil fauna is important to understand from the aspect of its nutritional type function. The process of eating and being eaten in the groove of the soil fauna food chain forms the characterization of the ecosystem of a land type so that this needs to be given attention to detailing the ecosystem conditions of a land type. 


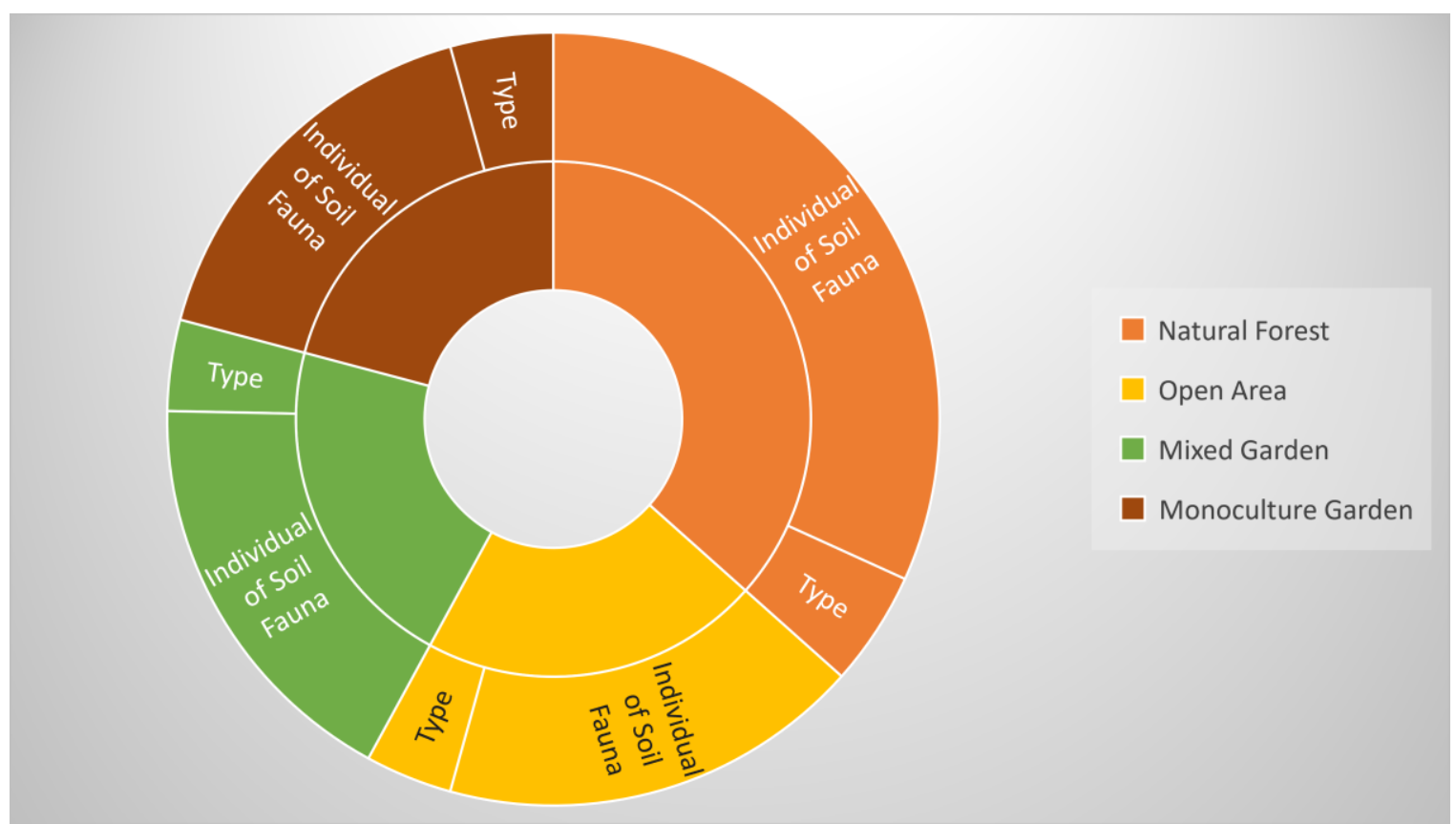

Figure 1: Functional abundance of soil fauna in several types of land in super wet tropical rain forest areas (Type and Individual functional soil fauna)

Figure 1. shows that the type of natural forest land has the highest abundance of species and functional individuals of soil fauna compared to other types of land. Furthermore, open land, mixed gardens and monoculture gardens have almost the same abundance of soil fauna. Forests as natural habitat Soil fauna is a productive place for soil fauna. According to [13] Certain regions of the world are known as centers of biodiversity, because they contain a high diversity of various levels of diversity, both the level of diversity of genes, species and ecosystems. Tropical rainforests are the peak point of biodiversity. Furthermore, according to [14] the interaction between soil fauna and its environment in tropical rainforest areas will form a mutualistic relationship in building the ecosystems of each land. [15] mentions that soil fauna groups are agents that assist in the supply of nutrient trees (symbiotic organisms) and recycling of primary production (decomposers), in which groups of soil fauna will carry out their activities alongside trees to ensure availability of nutrients. This is mainly due to the discovery of a mutualistic relationship between soil organisms, their immediate environment, and key processes such as litter decomposition, root growth, and forest dynamics.

Changes in land use in the super wet tropical rainforest area have caused a decrease in functional abundance of soil fauna (Fig. 1). according to [16] in agricultural practices, increasing the capacity of land to support high productivity causes loss of soil fauna useful to sustain the process of soil ecosystems in the agricultural area concerned. This can reduce the quality of the land. Furthermore [17] changes in forest land types will ultimately reduce the ability of soil ecosystem functions, such as decomposition and recycling of nutrients, which will be significantly reduced. According to [18] the scale of soil ecosystem quality will vary with the abundance of soil fauna, where the presence of human interference with functional processes that are irrelevant in the hierarchical position in the ecosystem is caused by symmetrical patterns of relationships between microbes, soil fauna, humus form and vegetation type. At present, knowledge has been reviewed and 
discussed in an integrated view of soil ecosystems, where studies of the role of soil fauna and its function in forest ecosystems need to be carried out.

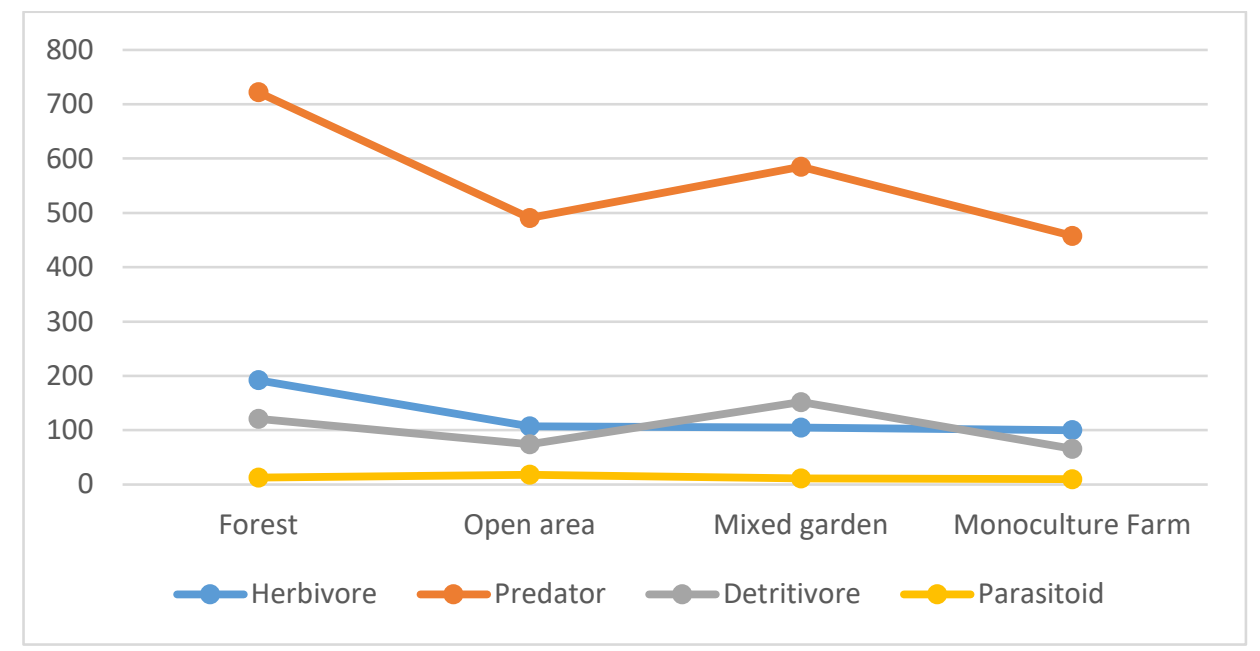

(a)

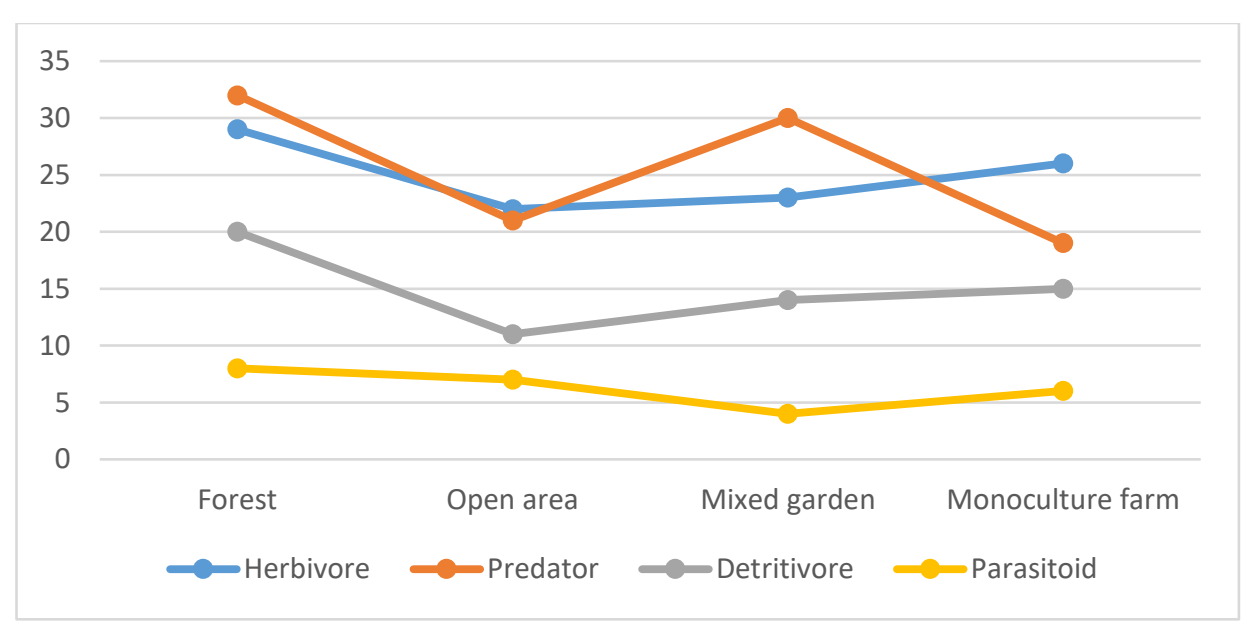

(b)

Figure 2: (a) Functional individuals of soil fauna, (b) Functional types of soil fauna, on several land types in the area of Padang's super wet tropical rainforest, Indonesia.

The results showed that soil fauna in the super wet tropical rain forest area was divided into several functional types consisting of herbivorees, predators, detritivore and parasitoid (Figure 2). On the functional graph of individual soil fauna in several types of land, super wet tropical rain forest (Figure 2a) shows that predatory soil fauna groups have higher abundance compared to other soil fauna functional groups, namely 722 in forest land types, 491 in land types open 585 on mixed plantation land types and 458 on monoculture land types. The high functional groups of predatory soil fauna are caused by the high food nutrition available in the super wet tropical rainforest area. According to [19] the abundance of functional individuals of soil fauna occurs due to the availability and variety of sources of nutrition, the interaction of biotic factors with biotic and abiotic such as climate, temperature and light intensity and land management, which directly affect agricultural productivity [20]. Species losses in ecosystems tend to be biased towards predators. According to [21] predators become a group of soil fauna that has a strong influence on ecological 
communities by controlling species abundance and dynamics at lower trophic levels. The high abundance of functional predators of soil fauna is due to the abundance of available food nutrients. According to [22] Predators tend to have extensive service provisions, where this group is able to regulate and control prey populations. According to [23] as an indicator of high species wealth that guarantees a balance of conservation, this group tends to be an early indicator of environmental damage that can cause loss of trophic level species at the bottom [24].

The abundance of herbivoreous individuals ranks second after predators in each land type in the super wet tropical rain forest area, except for mixed garden land types where the amount of detritivore is more than herbivorees. In the type of forest land found 192 the number of herbivorees, in the open land type found 107, in the type of mixed garden land 105 and in the type of monoculture garden land found 100 individual herbivoree fauna land. According to [25] Variations in the texture of vegetation can form herbivoreous soil fauna communities through effects on abundance, diversity, and distribution of host plants and natural enemies. Furthermore, [26] Throughout the Zone gradient or ecosystem type, herbivoreous wealth can be directly related to plant density, wealth, diversity, and sources of nutrition. In the landscape of tropical rainforest ecosystems there is a direct monotonous correlation between the wealth of herbivoreous soil fauna and the total abundance of plants and plant species richness. According to [27] the density of herbivorees that increases in open land types, mixed gardens and monoculture gardens is characterized by high densities in natural forests. [28] stated that the destruction and destruction of associated habitats would cause the loss of almost half of the herbivoreous soil species and potentially cause local extinctions. [29] states that in some cases, but not all, high densities of herbivorees are called epidemics, especially in areas of agricultural and plantation crops. We consider the outbreak to be a dramatic increase in the abundance of soil herbivorees that occur relatively in a short period and this is often associated with giving wounds to plants that exceed the aesthetic threshold. In many cases, herbivorees are associated with cultivated plants that have economic value and are considered pests.

The functional group of detritivore soil fauna has a varied abundance of individuals, where the highest abundance of detritivore is found in mixed garden land types, namely 152, in type 121 forest land, in open land type 74 and in monoculture land types 66. [30] says that detritus is a food source that supports trophic food chains in almost every heterotrophic field, has a high abundance of detritivore soil fauna. According to [31] detritivore soil fauna groups are the main "key" for nutrient mobilization in higher microbial and plant tissues. According to [32] functional density of soil fauna and metabolic rates of decomposer soil fauna is comparatively high in tropical rainforests but very little information is available on the functional roles of the diverging in tropical and subtropical ecosystems. Their contribution to ecosystems can only be assessed indirectly from performance criteria such as density, succession and diversity with regard to input of organic matter and inorganic nutrient output. [33] the impact of decomposer soil fauna on increasing nutrient availability in soil can be determined from the level of soil nutrient abundance. It is known that the incorporation of organic matter in the soil results in excessive growth of saprotrophic organisms. According to [31] changes in the type of natural forest land help in increasing the characteristics of edafics even though they occur at slow speeds for soil conservation by increasing nutritional status and the stability and diversity of the decomposer community. In general, decomposer fauna acts as a catalyst for microbial activity and hence can increase the progress of litter decomposition. 
The results showed that the abundance of parasitoid in several types of land super wet tropical rain forest area was open type 18, type of forest land area with the number 13, mixed garden land types with the number 11 and monoculture land types with a number 10. According to [34] The ability of soil fauna parasitoid to invade new parts of an area depends fundamentally on the abiotic and biotic elements of the environment being attacked. Large-scale human disturbances, such as expansion of agricultural land, have the potential for large-scale loss and fragmentation of natural habitats [35]. Loss of habitat and habitat fragmentation, according to [35] is one of the main causes of loss of biodiversity. The parasitoid soil fauna group has been predicted to be affected by habitat fragmentation. This is usually due to low population density which can increase the risk of extinction [36].

Figure 2 (b) shows the level of diversity of functional types of soil fauna, where in the type of forest, the predator group has the highest number of functional soil fauna, 32, then the number of functional species of soil fauna is 29 , detritivore is 20 and parasitoid is 8 . Furthermore, in the open land type functional group herbivore soil fauna has the highest value of 22, then the predator 21, detritivore 11 and parasitoid 7. In mixed garden types, the predatory fauna soil functional group has as much diversity as 30, then herbivores with a number of 23, detritivore 14 and parasitoid 4 . In monoculture land types herbivoree have the highest number of functional soil types 26 , predator 19, detritivore 19 and parasitoid 6. Diversity of functional types The fauna indicates that there is a variety of food nutrients available as well as vegetation and land management in the area. According to van [37] Changes in land types can cause habitat fragmentation which results in reduced diversity in the types of functional abundance of soil fauna and increases the possibility of local extinctions.

According to [35] general patterns have not yet appeared from the effects of habitat loss and fragmentation on functional types of soil fauna and their interactions with prey. According to [38] states that this can happen probably due to the generally functional types of herbivoreous, predatory, detritivore and parasitoid soil fauna that tend to make microhabitat or more important niches.

\subsection{Soil Fauna Food Web's for Several Types of Land Super Wet Tropical Rainforest Areas}

The pattern of soil fauna food web (Fig. 3) illustrates the pattern of relationships between interactions of biotic soil components consisting of producers, herbivorees, predators and detrivors in order to maintain ecosystem balance. Figure 3 shows the diversity of food web patterns on several types of land in the super wet tropical rain forest area. [39] in the mechanism of the food web, plants (land vegetation) play a key role in the two main supporters of life processes in the ecosystem, namely production and decomposition. According to [40] if trees (and possibly longlived plants) groups of soil fauna (especially herbivorees) will benefit from decomposition of substrate above the ground, where different species of plants can create sub-surface environments that will change the composition of soil fauna. In addition, the quality of litter which varies among tree species and plants in general, will affect the diversity of decomposers, food webs and nutrient cycles. 
Figure 3 shows that forest land types have higher herbivoreous, predatory and detritivore soil fauna diversity compared to other land types. Forest land vegetation consisting of tall and dense trees, thick litter, various types of shrub plants to several types of grass that grow above the ground, making this land type have a functional diversity of higher soil fauna. The pattern of relationship between food webs illustrated in Figure 3 shows that the group of coleoptera and orthoptera has the highest diversity of species in the functional fauna of herbivoreous soils. Where the diversity of coleoptera and orthoptera is 7 types each. According to [41] the properties of plants affect the presence and diversity of herbivorees and the interactions between predators and those who fall prey which then produce an indirect ecological effect.

Beetles are an important component of any type of agroecosystem land. According to [43] in recent years, significant progress has been made in barcoding associations between producers of plants and insects. [42] mention the majority of pioneering studies in this field were carried out on Coleoptera and Orthoptera [44]. The interaction between herbivoreous beetles and flowering plants has been postulated as the main driver of beetle diversity [45], as 135,000 of the 360,000 species of beetles are phytophagous [46], as interactions between groups of tropical insects and plants have been subjected to many other studies due to the very high diversity of both tropical plants and insects [37].

Predator abundance in each land type is found in the spider soil fauna group. The number of families of this soil fauna group dominates each type of land in the super wet tropical rainforest area. Forests have an abundance of spiders of 13 families, then 8 families of spiders in open land types, 14 spider families in mixed garden land types and 6 spider families in monoculture garden land types. According to [47] the abundance of spiders in a type of land raises the underlying assumptions in most trophic interaction models that all predators are a threat, in which prey responds to a similar way quantitatively, then [48] stated that this approach needs to abstract the mechanistic details of ecological interactions between species in food webs.

Research has shown that interspecific variations among prey and predator species, and even intraspecific variations in predatory species, can have a significant impact on community structure and regulation of ecosystem functions. [49] stated that the interaction of predatory individual species in food tissues can develop a more comprehensive theory of soil fauna community dynamics, where the nature of species interactions in ecological communities can dictate the effects transmitted through food webs both directly and indirectly.

The abundance of spiders in the type of agricultural land is biocontrol in crop pest control, where the main objective of agriculture is to maximize clean primary production. According to [50] research on the role of spiders in agroecosystem land types has focused primarily on the extent to which these predators suppress the density of herbivoreous grazing. [51] predator diversity is also determined by the diversity of herbivoreous prey that can affect the suppression of certain pest species through competition or indirect interactions mediated by host plants or together with predators. [52] one of the reasons for this increased diversity is the invasion of exotic pest species caused by global warming and global trade.

Detritivore is a group of soil organisms that acts as a decomposer that uses plant and animal serasah as well as other organic materials as a source of nutrition. The type of forest land is an area 
with the most diversity of orders among other types of land. This is because forests have a higher diversity of litter types than other types of land. According to [53] tropical forests, including those in Southeast Asia, are known as hotspots for global biodiversity. This loss of habitat will have an adverse effect on the level of global extinction. Furthermore, [54]) explains that detritivorous soil fauna groups are important ecologies in a type of land that play an important role in the decomposition process of leaf litter. Saprophagous soil fauna is the "key" for nutrient mobilization in plant tissues. when discussing functional diversity, in the decomposer system note that when soil fauna, namely the detritivore group in detrital food webs, is removed from the heterotrophic decomposition system, soil microbial activity can drop dramatically, which results in reduced carbon and nitrogen mineralization.

Such decomposition is an ecological service for the entire ecosystem, where $60-90 \%$ of terrestrial primary production is decomposed in soil. Decomposer soil fauna in increasing nutrient availability in the soil, where the incorporation of organic matter in the soil results in the growth of excessive saprotrophic organisms. According to [55] the community complexity of soil fauna structures, their interactions and functions in decomposition of organic matter and nutrient cycles are important aspects of litter decomposition studies, especially in tropical forests.

The diptera group is a soil fauna that dominates the diversity of detritivore in each type of land in the super wet tropical rain forest area (Figure 3). In the type of forest land, the diversity of soil fauna was listed by a total of 5 families, in open land areas there was a diversity of detritivore as many as 4 families, in mixed garden areas and monoculture gardens the diversity of soil fauna was detritivore as many as 7 families. [56] state that habitat fragmentation caused by changes in land use and the high level of agrochemical inputs in the field of crops are the main causes of rapid decline in biodiversity and this is commonly found in agricultural landscapes. In recent years, the study of detritivore flies has increased, where the detritivore fly group is the most striking and dominant group of insects compared to other types of insects. According to [57] the Diptera detritivore shows a broad ecological range, where this group acts as a catalyst for microbial activity and hence can increase the progress of litter decomposition. Interests vary relative to the volume of waste and the level of decomposition.

Changes in land use are the first step in the process of human welfare development. Cropping systems on agricultural land must continue to be adapted to meet farmers' needs and new goals in the context of socioeconomic changes [58]. Agricultural land developed to increase productivity to meet the demand for food and fiber has led to a simplification of crop diversity in fields, cropping systems and the level of agricultural landscapes, by increasing dependence on chemical inputs that can reduce beneficial biotic interactions [59]. Understanding the functional role of each trophic level of soil fauna from herbivorees, predators and detritivore in a food web system is an alternative to maintaining ecosystem sustainability in agricultural land types. 


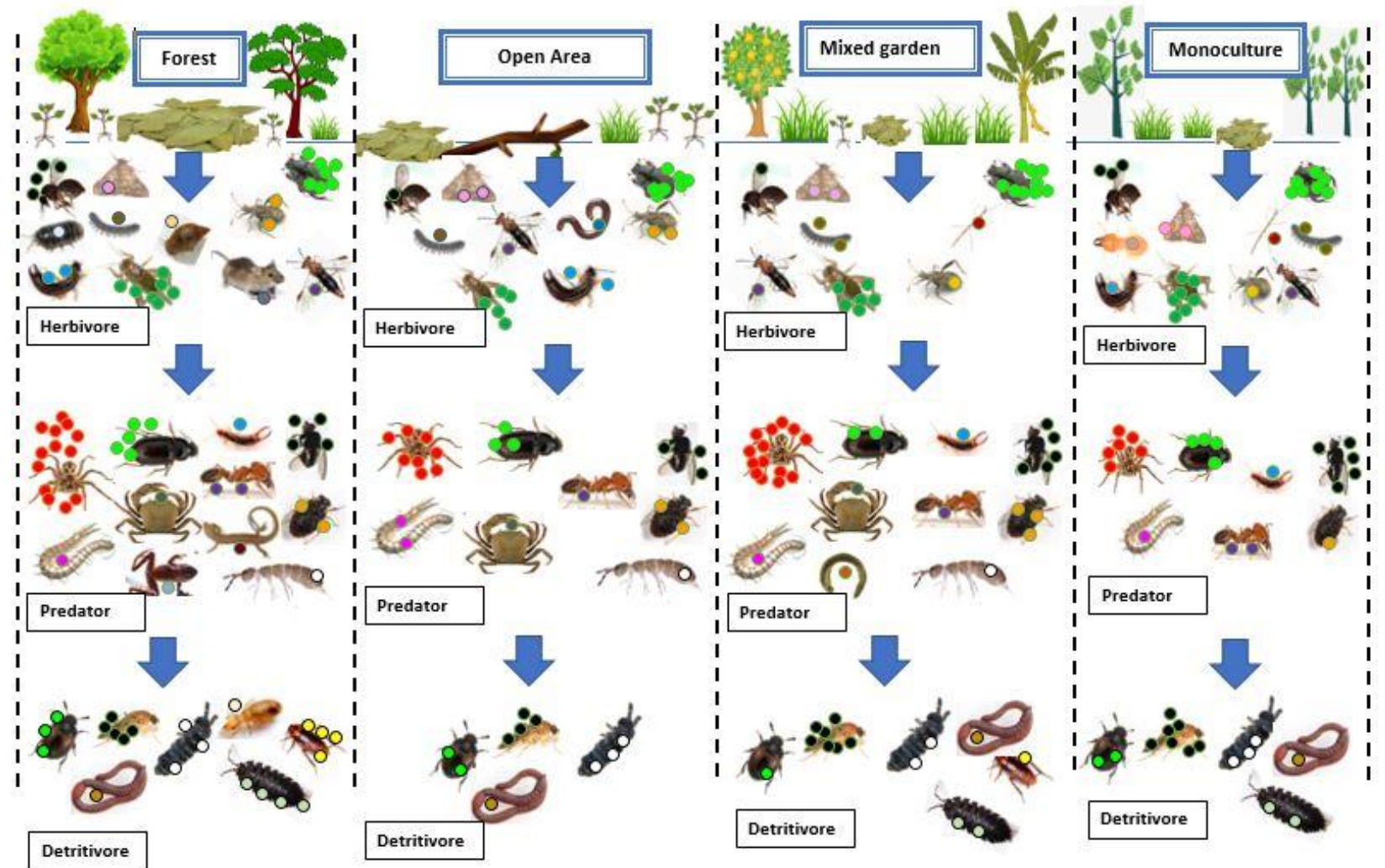

Figure 3: Visualization picture of the functional abundance components of soil fauna at each tropic level of food chain fauna in forest land types, open areas, miled gardens and monoculture gardens; a sign indicating the amount of soil fauna.

\section{Conclusions}

The abundance characteristics of the highest functional individuals of soil fauna in each land type in the super wet tropical rainforest area, namely the predator group and the characteristics of the lowest number of functional individuals of soil fauna are the parasitoid group. while from the aspect of the diversity of functional types of soil fauna shows different dominance on each type of land, where forests are dominated by predator groups, open land types are dominated by herbivores, mixed gardens are dominated by predators and monoculture garden types are dominated by herbivores. The food net pattern in each type of super wet tropical rainforest area shows a balance of energy flow that is still stable in forest land types and mixed gardens, where the diversity characteristics of predators have a higher number of herbivorous groups. whereas for open land types and monoculture gardens with high levels of herbivorous diversity indicate that the land has the potential for pest disturbance. So that changes in vegetation type of land in super wet tropical rainforest will cause fragmentation of functional habitat of soil fauna which causes imbalance in the flow of energy in food webs.

\section{Acknowledgements}

The Author thanks to DIKTI Indonesia through PMDSU Scholarship for research support and assistance costs until the research was completed. 


\section{References}

[1] Hansen R.A., Diversity in the decomposing landscape, in: Coleman D.C., Hendrix P.F. (Eds.), Invertebrates as webmasters in ecosystems, CABI Press, Wallingford, U.K., 2000, 203-219.

[2] Duffy, J. E., Carinele, B. J., France, K. E., Mcintyre, P. B., Thebault, E. \& Loreau, M, The functional role of biodiversity in ecosystems: incorporating trophic complexity. Ecology Letters, $10,2007,522-538$.

[3] de Vries, F.T., Thébault, E., Liiri, M., Birkhofer, K., Tsiafouli, M.A., Bjørnlund, L., Jørgensen, H.B., Brady, M.V., Christensen, S., de Ruiter, P.C., d'Hertefeldt, T., Frouz, J., Hedlund, K., Hemerik, L., Hol, W.H.G., Hotes, S., Mortimer, S.R., Setälä, H., Sgardelis, S.P., Uteseny, K., van der Putten, W.H., Wolters, V., Bardgett, R.D., Soil food web properties explain ecosystem services across European land use systems. PNAS, 110, 2013, 14296-14301.

[4] Trap, J., Bonkowski, M., Plassard, C., Villenave, C., Blanchart, E., Ecological importance of soil bacterivores for ecosystem functions. Plant Soil, 2016, 1-24.

[5] Briones, M.J.I, Soil fauna and soil functions: a jigsaw puzzle. Front. Environ. Sci, 2, 2014, 1- 22.

[6] Wardle, D.A., Bardgett, R.D., Klironomos, J.N., Setala, H., van der Putten, W.H., Wall, D.H, Ecological linkages between aboveground and belowground biota. Science, 304, 2004, 1629-1633.

[7] Cammeraat, E.L.H., Risch, A.C, The impact of ants on mineral soil properties and processes at different spatial scales. J. Appl. Entomo, 132, 2008, 285-294.

[8] Hermansah, Nutrient Cycle and Its Relationship to Plant Species Diversity in West Sumatra Tropikal Rain Forest: Specific Plant Leaf Decomposition Rate. Research Report. Lembaga Penelitian Univ. Andalas. Padang, 2010.

[9] Singh, J.S., Vimal C.P., D.P. Singh, Efficient soil microorganisms: A new dimension for sustainable agriculture and environmental development. Agriculture, Ecosystems and Environment, 140, 2011, 339-353.

[10] Garbach, K., J.C Milder., M.Montenegro and D.S Karp., F.A.J DeClerck, Biodiversity and Ecosystem Services in Agroecosystems. Encyclopedia of Agriculture and Food Systems, 2, 2014, 21-39.

[11] Berg, M.P., and Bengtsson, J, Temporal and spatial variability in soil food web structure. Oikos, 116, 2007, 1789-1804.

[12] Holtkamp, R., Paul, K., Annemieke W., Stefan C., Wim H.,Putten, Peter C. de Ruiter, Soil food web structure during ecosystem development after land abandonment. applied soil ecology, 39, 2008, 23-34.

[13] Gray, J, Major Paleozoic land plant evolutionary bio-events, Palaeogeogr. Palaeoclimatol. Palaeoecol, 104, 1993, $153-169$.

[14] Wolters V., Silver W.L., Bignell D.E., Coleman D.C., Lavelle P., van der Putten W.H., de Ruiter P.C., Rusek J., Wall D.H., Wardle D.A., Brussaard L., Dangerfield J.M., Brown V.K., Giller K.E., Hooper D.U., Sala O., Tiedje J.M., van Veen J.A, Effects of global changes on above- and belowground biodiversity in terrestrial ecosystems: implications for ecosystem functioning, BioSience, 50, 2000, 1089-1098.

[15] Lavelle, P., Eric, B., Agnes, M., Serge, M.Alister, S, A Hierarchical Model for Decomposition in Terrestrial Ecosystems: Application to Soils of the Humid Tropiks. Biotropika, 25(2), 1993, 130150.

[16] Doran, J.W., M.R.Zeiss. Soil health and sustainability: managing the biotic component of soil quality, Applied Soil Ecology, 15, 2000, 3-11.

[17] Blagodatsky, S \& Smith, P, Soil physics meets soil biology: Towards better mechanistic prediction of greenhouse gas emissions from soil, Soil Biology and Biochemistry, 47, 2012, 78-92.

[18] Wolters V., Silver W.L., Bignell D.E., Coleman D.C., Lavelle P., van der Putten W.H., de Ruiter P.C., Rusek J., Wall D.H., Wardle D.A., Brussaard L., Dangerfield J.M., Brown V.K., Giller K.E., Hooper D.U., Sala O., Tiedje J.M., van Veen J.A, Effects of global changes on above- and 
belowground biodiversity in terrestrial ecosystems: implications for ecosystem functioning, BioSience, 50, 2000, 1089-1098.

[19] Siqueira, G.M., Silva, E.F.F., Vidal-Válquez, E., Paz-González A, Multifractal and joint multifractal analysis of general soil properties and altitude along a transect. Biosyst Eng, 2017, In press.

[20] Basso, F.C., Andreotti, M., Carvalho, M.P., Lodo, B.N, Relações entre produtividade de sorgo forrageiro e atributos físicos e teor de matéria orgânica de um Latossolo do Cerrado, Pesq Agropec Trop, 41, 2011, 135-44.

[21] Loreau, M., Nicolas, M., Robert D. H, Meta-ecosystems: a theoretical framework for a spatial ecosystem ecology, Ecology Letters, Vol.6, No.8, 2003, 673-679.

[22] Dobson, A., Lodge, D., Alder, J., Cumming, G.S., Keymer, J. \& McGlade, J, Habitat loss, trophic collapse, and the decline of ecosystem services, Ecology, 87, 2006, 1915-1924.

[23] Sergio, F., Newton, I., Marchesi, L. \& Pedrini, P, Ecologically justified charisma: preservation of top predators delivers biodiversity conservation, J. Appl. Ecol, 43, 2006, 1049-1055

[24] Halpern, B.S., Borer, E.T., Seabloom, E.W. \& Shurin, J.B, Predator effects on herbivora and plant stability, Ecol. Lett, 8, 2005, 189-194.

[25] Griffin, J.M., Turner, M.G., Simard, M. Nitrogen cycling following mountain pine beetle disturbance in lodgepole pine forests of Greater Yellowstone. Forest Ecol. Manag 261, 2011, 10771089.

[26] Raupp,M.J., Paula M., Shrewsbury,and Daniel A, Ecology of Herbivoraous Arthropods in Urban Landscapes. Annu. Rev. Entomol, 55, 2010, 19-38.

[27] Tuomi, J., Haukioja, E., Honkanen, T., \& Augner, M, Potential Benefits of Herbivora Behaviour Inducing Amelioration of Food-Plant Quality, Oikos, Vol. 70, No.1, 1994, 161

[28] Hafernick, J.E., Reinhard, H, Butterflies by the Bay: winners and losers in San Francisco's urban jungle, Am. Butterflies, 3, 1995, 4-11

[29] Berryman, A.A, The theory and classification of outbreaks. In Insect Outbreaks, ed. P Barbosa, JC Shulz, 1, 1987, 3-30

[30] Hanski, I, Nutritional ecology of dung and carrion feeding insects. In Nutritional Ecology of Insects, Mites, Spiders, and Related Invertebrates, ed. F. Slansky Jr. and J. G. Rodriguez, 1987, 837-85, New York: John Wiley and Sons.

[31] Pramanik, K. Sarkar \& V.C. Joy, Efficiency of detritivoree soil arthropods in mobilizing nutrients from leaf litter. Tropikal Ecology Vol.42, No.1, 2001, 51-58.

[32] Lee, K.E, The role of soil fauna in nutrient cycling, In: G.K. Veeresh, D. Rajagopal \& C.A. Viraktamath (eds.) Advances in Management and Conservation of Soil Fauna. Oxford \& IBH Publ. Co. Pvt. Ltd., New Delhi, 1991, 465-472.

[33] Wolters, V. \& K. Ekschmitt, Gastropods, Isopods, Diplopods \& Chilopods; Neglected groups of the decomposer food web.. In: G. Benckiser (ed.) Fauna in Soil Ecosystems. Marcel Dekker Inc., New York, 1997, 265-306.

[34] Stevens, N.B., Syngeon M. R., Tamara C. O'. K and David A. J, The use of the biodiverse parasitoid Hymenoptera (Insecta) to assess arthropod diversity associated with topsoil stockpiled for future rehabilitation purposes on Barrow Island, Western Australia. Records of The Western Australian Museum, 2013, 355-374.

[35] Fahrig, L, Effects of Habitat Fragmentation on Biodiversity. Annu. Rev. Ecol. Evol. Syst, 34, 2003, 487-515.

[36] Swif, T.L \& S.J. Hannon, Critical thresholds associated with habitat loss: a review of the concepts, evidence, and applications, Biol. Rev 85, 2010, 35-53

[37] Novotny, V., Miller, S.E., Hulcr, J., Drew, R.A., Basset, Y., Janda, M., Setliff, G.P., Darrow, K., Stewart, A.J., Auga, J., Isua, B., Molem, K., Manumbor, M., Tamtiai, E., Mogia, M., Weiblen, G.D, Low beta diversity of herbivoraous insects in tropikal forests. Nature 9, 448(7154), 2007, 692695. 
[38] Meissner, K., Juntunen, A., Malmqvist, B \& Muotka, T, Predator-prey interactions in a variable environment: responses of a caddis larva and its blackfly prey to variations in stream flow, Annales Zoologici Fennici, 46, 2009, 193-204.

[39] Manlay, R., Kaïré, M., Masse, D., Chotte, J.L., Ciornei, G., Floret, C, Carbon, nitrogen and phosphorus allocation in agro-ecosystems of a West African savanna. I. The plant component under semi- permanent cultivation. Agriculture, Ecosystems and Environment, 88, 2002, 215-232.

[40] Wardle, D.A, The influence of biotic interactions on soil biodiversity, Ecol. Lett 9, 2006, 870-886.

[41] Whitham, T. G., W. P. Young, G. D. Martinsen, C. A. Gehring, J. A. Schweitzer, S. M. Schuster, G. M. Wimp, D. G. Fischer, J. K. Bailey, R. L. Lindroth, S. Woolbright, and C. R. Kuske, Community and ecosystem genetics: a consequence of the extended phenotype, Ecology 84, 2003, $559-573$.

[42] Kishimoto-Yamada, K., Hyodo, F., Matsuoka, M., Hashimoto, Y., Kon, M., Ochi, T., Yamane, S., Ishii, R., Itioka, T, Effects of remnant primary forests on ant and dung beetle species diversity in a secondary forest in Sarawak, Malaysia. J Ins Conserv 17, 2013, 591-605.

[43] Matheson, C.D., Müller, G., Junnila, A., Vernon, K., Hausmann, A., Miller, M.A., Greenblatt, C. $\&$ Y. Schlein, A PCR Method for Detection of Plant Meals from the Gut of Insects. Organisms, Diversity \& Evolution 7, 2008, 294-303

[44] Ibanez, S., Manneville, O., Miquel, C., Taberlet, P., Valentini, A., Aubert, S., Coissac, E., Colace, M.P., Duparc, Q., Lavorel, S., Moretti, M, Plant functional traits reveal the relative contribution of habitat and food preferences to the diet of grasshoppers. Oecologia, 173, 2013, 1459-1470.

[45] Farrel, B.D. 1998. Inordinate Fondness" Explained: Why Are There So Many Beetles?. Science, Vol.281, No.5376, 1998, 555-559.

[46] van Nouhuys, S., Hanski, I, Multitrophic interactions in space: metacommunity dynamics in fragmented landscapes. Cambridge University Press, 2002, 124-147

[47] Krivan, V, Competitive coexistence caused by adaptive predators, Evol. Ecol. Res 5, 2003, $1163-$ 1182.

[48] Pollierer, M.M., Langel, R., Scheu, S. \& Maraun, M, Compartmentalization of the soil animal food web as indicated by dual analysis of sTabel isotope ratios (15N/14N and 13C/12C), Soil Biol Biochem 41, 2009, 1221-1226.

[49] Schmitz, O. J, Effects of Predator Hunting Mode on Grassland Ecosystem Function. Science, Vol. 319, No.5865, 2008, 952-954.

[50] Gerben, J.M., L.W. Kok., C. M. J. Bloemhard.,Arne, J, Generalist predatory bugs control aphids in sweet pepper. Integrated control in protected crops temperate climate IOBC/wprs Bulletin, 68, 2011, 115-118.

[51] Cakmak, I., Arne, J., Maurice, W., Sabelis., Huseyin, B, Biological control of an acarine pest by single and multiple natural enemies, Biological Control, 50, 2009, 60-65.

[52] Roques, A., Rabitsch, W., Rasplus, J-Y., Lopez-Vaamonde, C., Nentwig, W., Kenis, M, Alien terrestrial invertebrates of Europe. In: DAISIE (ed) Handbook of alien species in Europe. Springer,Dordrecht, Netherlands, 2009, 63-79

[53] Boyero, L., Ramı'rez, A., Dudgeon, E. \& Pearson, R.G, Are tropikal streams really different?. J. N. Am. Benthol. Soc., 28, 2009, 397-403.

[54] Dudgeon, D., A.H. Arthington, M.O. Gessner, Z. Kawabata., D. Knowler., C. Lévêque., R.J. Naiman., A-H APrieur-Richard., D. Soto., M.L.J. Stiassny and C.A. Sullivan, Freshwater biodiversity: importance, status and conservation challenges, Biological Reviews of the Cambridge Philosophical Society, 8, 2006, 163-182.

[55] Ananthakrishnan, T.N, Forest Litter Insect Community. Biology and Chemical Ecology. Oxford and IBH Publ. Co. Pvt. Ltd., 1996, New Delhi.

[56] Farwig, N., Bailey, D., Bochud, E., Herrmann, J.D., Kindler, E., Reusser, N., Schüepp, C., SchmidtEntling, M.H, Isolation from forest reduces pollination, seed predation and insect scavenging in Swiss farmland, Landsc Ecol, 24, 2009, 919-927. 
[57] Rabieh, M., Mahmoud, A., Touraj, A., Meisam,T., E. P. Nartshuk, Checklist of Grass Flies (Diptera: Chloropidae) of Markazi province, Iran. Int. J. Dipterol. Res, Vol. 23, No.2, 2012, 95101.

[58] Boivin, N.L., Zeder, M.A., Fuller, D.Q. 2016. Ecological consequences of human niche construction: examining long-term anthropogenic shaping of global species distributions. Proc. Natl. Acad. Sci. U. S. A, Vol.113, No.23, 2016, 1753-1773.

[59] Stoate, C., Boatman, N. D., Borralho, R. J., Carvalho, R. C., de Snoo, G. R., \& Eden, P, Ecological impacts of arable intensification in Europe. Journal of Environmental Management, 63, 2001, 337365.

*Corresponding author.

E-mail address: fenkysandi90@ gmail.com 